an International Congress of Physical Chemistry to meet in Paris in the third week of October of this year. Foreign scientific societies have been invited to collaborate. In addition to the usual receptions, banquets, etc., a series of discussions are being organised, dealing with outstanding physico-chemical problems, such as electronic conduction in metals and its relation to electrochemical phenomena. Communications upon this and other questions have been invited from eminent men of science in France and in foreign countries. These will be discussed at the forthcoming conference and will be published afterwards by the Société de Chimie Physique. Further information concerning the Congress may be obtained from Dr. Ch. Marie, 9 rue de Bagneux, Paris, 9e.

\section{Mercury Arc Rectifiers}

IN the Brown Boveri Review for October a very impressive list is given of the mercury arc rectifiers for power transmission which the firm has shipped to overseas countries. We are glad therefore to learn that these important devices for converting alternating into direct current are now being made in Great Britain by several manufacturers. For shipping abroad it is necessary that apparatus be provided with spare parts. For rectifiers these spare parts are made of porcelain, iron and steel. They cost little and can easily be kept in good condition. Two alternating current stations can be connected by a direct current link connected through two rectifiers. One rectifier converts A.C. to D.C. and the other converts D.C. to A.C. This arrangement is economical when the voltage at which power is interehanged through the link is high. This has led to the development of high-tension rectifiers. Pressures up to 50,000 volts have already been attained. Vacuum rectifiers are independent of the frequency. Mercury arc rectifiers do not operate at frequencies higher than about three thousand but from the practical point of view this matters little. It is probable that rectifiers may be used in the future for converting A.c. into D.C. for transmission along overhead wires, as difficulties arise in transmitting A.c. along these wires at full loads. If long-distance electrification of railways is ever adopted in Great Britain they would be most useful, for whatever systems are adopted by various companies, power on any other system can be transmitted to them and converted.

\section{Meteorology in Southern Rhodesia}

The most recent Meteorological Report of the Department of Agriculture of Southern Rhodesia covers the year ending June 30, 1931. Included with it as an appendix is the Hydrographic Report for the years ending September 30, 1928, 1929, 1930 and 1931-a summary of rainfall and run-off for certain catchment areas in Southern Rhodesia, occupying four pages. The Meteorological Report contains the usual general review of the year, particulars of the climatological stations-which are all in the charge of voluntary observers or observers attached to departments other than the Department of Agriculture-and numerous climatic tables, together with a few miscellaneous items, including a tentative essay in the preparation of seasonal forecasts of rainfall based on a number of factors, such as barometric pressure at Rio de Janeiro.

THE results obtained so far indicate a degree of success that would, if maintained, be of great economic importance in agriculture, but unless the correlation coefficient of +0.77 proves to have been an under-estimation of the degree of dependence of Rhodesian rainfall on the various factors from which it is being calculated, such successes will occasionally in future years be replaced by failures or partial failures. These should not, however, be frequent enough to make the forecasts useless to those with an intelligent appreciation of the proportion of success to be expected from given values of the correlation coefficient. Southern Rhodesia is one of those regions where the success of farming operations is very dependent upon a monsoonal rainfall that may seem ideal when the average only is considered, but which is capricious as regards its occurrence in individual years, and is too apt to occur in torrential downpours that result in an excessive loss to the soil through run-off at the surface. When farmers must face the lean years of deficient rainfall at a time of agricultural depression, it is not surprising that many fail and abandon their farms. This is mentioned in the Report as one of the factors contributing to a net loss of 32 observing stations in the eighteen months ending December 31, 1931.

\section{Marine Biology in Ceylon}

Dr. Joseph Pearson, in his Administrative Report of the Marine Biologist for the Year 1931 (Part IV : Education Science and Art (G). Colombo : Government Record Office, 1932), states that the year's inspection of the Ceylon pearl banks has not brought to light any new spat falls and as there are no mature oysters in large quantities at present, there is no prospect of a pearl fishery for at least another four years. The dredgings in the Gulf of Mannar, however, showed small patches of young oysters on practically all the paars, which is a promising sign for repopulation of the banks, as the heavy spat falls of 1921-24 followed a similar scattering of young oysters in 1920. During the diver's inspection of the pearl banks, in one or two places dense masses of Avicula spat were found attached to the Sargassum weed. This is known as 'false spat' and used often to be taken for the spat of the pearl oyster. The report also contains notes on the window-pane oyster fishery, chank fisheries and local fishing industries. Plans for development are sketched out and it is hoped that a fishing vessel of a modern type will soon be available by the aid of which it is proposed to carry out detailed investigations and research necessary to determine the best methods to be adopted for the bettering of the fishing industry by the introduction of modern fishing craft and modern fishing appliances. 